\title{
Erratum: Oxygen depletion recorded in upper waters of the glacial Southern Ocean
}

Zunli Lu, Babette A.A. Hoogakker, Claus-Dieter Hillenbrand, Xiaoli Zhou, Ellen Thomas, Kristina M. Gutchness, Wanyi Lu, Luke Jones \& Rosalind E.M. Rickaby

Nature Communications 7:11146 doi: 10.1038/ncomms11146 (2016); Published 31 Mar 2016; Updated 26 Apr 2016

In Fig. 3 of this Article, data in panel 'a' were inadvertently partially obscured during the production process. The correct version of Fig. 3 now appears in the PDF and HTML versions of the Article. article's Creative Commons license, unless indicated otherwise in the credit line; if the material is not included under the Creative Commons license, users will need to obtain permission from the license holder to reproduce the material. To view a copy of this license, visit http://creativecommons.org/licenses/by/4.0/
} 